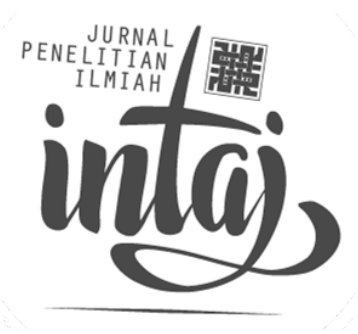

\title{
THE EFFECTIVENESS OF TWO STAY TWO STRAY TECHNIQUE IN TEACHING READING COMPREHENSION
}

\author{
Nur Ali (nuraremaali@gmail.com) \\ Institut Agama Islam (IAI) Al-Qolam Malang
}

(Received: Agustus 2018 / Revised: Agustus 2018 / Accepted: September 2018)

\begin{abstract}
Penelitian ini menyelidiki sejauh mana pengaruh strategi two stay two stray dalam mengajar pemahaman membaca teks bahasa Inggris, yang menggunakan kuasi-faktorial dengan desain pretestposttest. Temuan penelitian ini memberikan bukti pengaruh yang signifikan secara statistik antara sebelum dan sesudah tes. Dengan kata lain, adanya perbedaan yang signifikan setelah diajarkan dengan menggunakan strategi two stay two stray. Hal ini dipengaruhi oleh beberapa faktor. Pertama, pelaksanaan atau manifestasi strategi two stay two stray membantu siswa untuk mudah memahami informasi yang mereka dapatkan dari bahan bacaan dengan cara efektif. Kedua, melatih siswa untuk mencari kata kunci dari setiap paragraf dengan mudah dan menuliskan informasi dari kata kunci tersebut. Ketiga, memberikan kesempatan bagi siswa untuk mengingat informasi detail dari bahan bacaan. Selain itu, kegiatan meringkas membantu siswa untuk menganalisis dan mengevaluasi informasi yang didapat dari bacaan. Dengan demikian, siswa dilatih untuk berpikir kritis dan efektif dalam kegiatan pembelajaran di setiap per-temuan. Strategi two stay two stray membuat siswa antusias dan jauh dari kata bosan pada setiap kegiatan pembelajaran khu-susnya pada materi pemahaman bacaan teks Bahasa Inggris.
\end{abstract}

Kata Kunci: Strategi two stay two stray, Reading comprehension 


\section{BACKGROUND OF THE STUDY}

Language is built into the way people live that it has become an axiom of being human. Language is one of the ways that human can communicate with other people. It is the attribute that most clearly distinguishes our species from all others. Language can express feeling, thoughts and ideas to other people. Language is so important for our life of coure. It can not be denied that used language in order to the people can understand what we mean. One of the most important languageswhich are often used as a tool of communication among countries in this world is English. In Indonesia, English becomes more important. English is one of the primary subjects at school that gets 4 hours/week. ${ }^{1}$

As we know that English is an international language and a compulsory subject must be learnt by all students in Indonesia. Learning English is becomingimportant thing for people to be more competitive and innovative in all aspects of life such as education, technology, and social-culture. As an international language, English has gained the popularity all over of the world including Indonesia.

The Indonesian government has acknowledged the important of English, by putting into education English is becomes as one of the compulsory subject at many schools in Indonesia. The national education department decides that Indonesian students must have the competence of understanding and expressing information ideas, feeling and developing science, technology, and culture in English. ${ }^{2}$

In the teaching English, there are four language skills that the students need to master. They are Speaking, Writing, Listening and Reading, Those skills have an important role to gain effective English. In the teaching and learning process, the fourth language skills are taught and developed, but reading skill is the most im-

\footnotetext{
${ }^{1}$ Depdiknas, Permendiknas 2006 tentang SI \& SKL. (Jakarta: Departemen Pendidikan Nasional, 2006)

${ }^{2}$ Endang fauziati, Teaching of English as a Foreign Language (Surakarta: Muhammadiyah Press, 2002),p.169.
} 
portant skill that can support to mastery the other skills. Reading is an interactive process that goes on between the reader and the text, resulting in comprehension. The text present sentences, letters, words and paragraphs that encode meaning. The readers use knowledge, skills, and strategies to determine what that meaning is. ${ }^{3}$

Reading is not only the simply form of written language. The students should know how to comprehend the content side of the reading text. Moreover, they should make a great effort and train to understand the message that is given by author of the text. Based on the writer's experience in teaching practice, the students' reading mastery is still unsatisfactory. They always get difficulties and they do not understand what the text is about. These phenomena might be caused by several problems. The problems are affected by two main factors, internal and external factors. The first factor is the internal factor. This factor arises from the students. Students' vocabulary is not satisfactory yet. Students are not able to understand texts, they encounter words that have actually been taught or told to them, not to mention if they find new words and also.

The second one is the external factor. The causes are from outside. Such as the teacher tend to emphasize more on students' reading result, not on the learning process. Teachers usually do not pay attention to the learning process but the result of the learning. Teachers are more concerned with the scores students obtain rather than the process of making students understand. Sometimes, the technique which the teacher uses still conventional, it has disadvantages such as the method that can bring students out of boring, monotonous, individual class atmosphere and passive students because the teacher is dominant in the class and to be teacher centered. It means that the teacher should used good strategy or learning model in learning process.

In reading comprehension, students should have ability to understand the text well. So, English teacher had better to prepare their students should be competent in reading. In the reading a text, the students usually find some difficulties when they are

\footnotetext{
${ }^{3}$ http ://www.nclcr.org/ essentials/reading/ reindex.htm accessed on October,24,2014
} 
learning about text, because in the text sometime more difficult to understand about meaning, vocabulary, and what the text is. Texts can be difficult or easy, depending on factors inherent in the text, on the relationship between the text and the knowledge and abilities of the reader, and on the activities in which the reader is engaged. For example, the content presented in the text has a critical bearing on reading comprehension.

A reader's domain knowledge interacts with the content of the text in comprehension. For most of the students reading comprehension is more than a problem. When students are asked if they like to read in English most of them will probably answer no explaining that reading is such a boring activity for them or they do not like the type of texts they are provided. The biggest problem is that when students read a text they are so worried about understanding every single word that they do not get the general idea from the passage. ${ }^{4}$

Technique of two stay two stray (dua tinggal dua tamu) is one of the cooperative learning model which provides an opportunity to share the result and other information to the group. This is done because a lot of teaching and learning that characterized the activities of the individual. Two stay two stray technique can give a little picture to the students about the reality of life in society, that is in the life of the society needed relationship dependence and social interaction between individuals with other individuals with gorup. The use of two stay two stray technique will direct students to be active, both in discussion, question and answer, seeking answers, explaining and also listening to the material described by friends. In addition, the reason to use two stay two stray technique is because there is a clear division of group work each group member, students can work with friends to solve the problem, can overcome the condition of students who are crowded and unruly during the teaching and learning process.

\footnotetext{
${ }^{4}$ Guadalupe Vázquez Granados and Gustavo Hernández López,Ten suggestions for solving reading problems in English, (Universidad de Quintana Roo - Departamento de LenguayEducación, 2008), p. 15
} 
The purpose of this strategy makes the students are more active, through discussions, ask questions, seek answers, explain and also listen to the material described by a friend. In this lesson, the students are exposed to events by listening to what is being said while visiting his friend, who is not directly the students will be taken to listen to what is being said by members of the group who hosted them. In this process, there will be activities on students' listening material.

\section{RESEARCH METHOD}

\subsection{Design}

The study attempted to finddout the effect of two stay two stray technique on reading comprehension. As stated in chapter I, the problem of this research is to know whether there is any difference in achievement of the students' reading comprehension taught by the two stay two stray technique than those taught by jigsaw technique. Thereby, to obtain the precise measurement of the effectiveness of two stay two stray technique on students' reading comprehension achievement, the reaseacher needs to choose a research design to allow the researcher to measure it precisely. Thus, this reseachhwould be best conducted in an experimental research.

In this research, it is used the excitinggclassess for the experimental group and the control group. Further due to inability of assigning subejct to groups randomly in MA Darul Ulum Sukosari Gondanglegi Malang, this research uses quasi experimental design. Quasi-experimental designs are similiar to randomized experimental designs in that they involve manipulation of an independent variable but differ in that subjects are not randomly assigned to treatment groups. ${ }^{5}$

The choice of this design was under the following considerations. This study was carried out in a classroom setting where random assignments of subject could not be conducted and the two groups of subjects is provided by the school authority,

\footnotetext{
${ }^{5}$ Donald Ary, et al. Introduction to Research in Education, (Canada:WadswortCengage Learning 2010), p.316
} 
even though the selection which group was experimental group or control group was selected randomly. In a school situation, schedules can be disrupted or classes reorganized to accommodate this research study. Thus, it was not necessary to use groups as they are already organized into classes.

\subsection{Population and Sample}

The population of the study was the tenth grade students of MA Darul Ulum Gondanglegi Malang in the academic year 2017/2018, there was one class (X). The population and sample of the study was presented in the following table.

Table 1:

The Population of the Study

\begin{tabular}{cc}
\hline Class & Number of Students \\
\hline$X$ & 30 \\
\hline Total & 30 \\
\hline
\end{tabular}

In the present research, simple random sampling was carried out in the population. It was carried out by doing lottery. The lottery was carried out towards the two classes of the population. Basically, each of the groups had the same possibility to be the sample of the research. Based on the result of the lottery showed that X-A1 was chosen as the experimental group and X-A2 was chosen as the control group.

\subsection{Treatment}

In the experiment, the two reading strategies were implemented during the treatment. The two stay two stray strategy was implemented to the experimental group and the jigsaw teaching strategy was implemented to the control group. At the end of the experiment, both of the groups were post-tested. The treatment for both groups lasted for eight meetings.

Since the two stay two stray strategy was a new strategy for the experimental group, the treatment for the experimental group was carried out into three steps: modeling, guiding, and practicing. In the modeling step and guiding step, the teacher trained 
students by giving models on how to find keywords and its description and after that the teacher let students find keywords by themselves with sufficient guidance from the teacher. This modeling and guiding step was carried out for the first four meetings. After that, in the practicing stage, in the fifth up to eighth meeting, students practiced to find keywords and its description without any intervention from the teacher.

According to the syllabus for the tenth grade of senior high school, the text types used in the treatment was narrative. The schedule of the treatment for both groups is presented in the following tables.

Table 2.

The Schedule of the Treatment for the Experimental Group and Control Group

\begin{tabular}{cll}
\hline MEETING & \multicolumn{1}{c}{ EXPERIMENTAL GROUP } & \multicolumn{1}{c}{ CONTROL GROUP } \\
\hline 1 & Pre-test (Narrative) & Pre-test (Narrative) \\
\hline 2 & Modeling \& Guiding & Narrative \\
\hline 3 & Modeling \& Guiding & Narrative \\
\hline 4 & Modeling \& Guiding & Narrative \\
\hline 5 & Practicing & Narrative \\
\hline 6 & Practicing & Narrative \\
\hline 7 & Practicing & Narrative \\
\hline 8 & Post-test (Narrative) & Post-test (Narrative) \\
\hline
\end{tabular}

Similarly, the procedures of teaching jigsaw strategy are followed by the three phases proposed by the experts mentioned previously. However, different from the procedures of teaching two stay two stray strategy for experimental group, the teaching of jigsaw strategy for the control group did not have three stages of teaching technique as for the experimental group. The treatments are: pre-reading activity, whilst-reading activity and post-reading activity. 


\subsection{Instruments}

There were two instruments applied in this study: a reading comprehension test and questionnaire. The topic for reading comprehension was designed to be different as a researcher assumed that students could not remember what they have carried out incorrectly in the pretest. The questionnaire used to know the students' attitude toward the strategy is applied in this study.

In order to measure the effectiveness of the independent variable on the dependent variable, the instrument used to get the data of students' reading achievement is posttest. It was administered after applying the treatment to the experimental group.

In designing and analyzing the test instrument of reading test, the procedures about how to make a good test were followed. The blueprint was prepared and the expert validations were needed to judge whether the test was good or not. Before using the test measure the students' achievement in reading, the instrument had to be tried out to consider the validity and the reliability of the test. The item of the test was selected and analyzed based on expert validation and face validity.

The reading comprehension test was a multiple choice type, having five options for each item with only one correct answer. The reason for using the multiple choice format was based on practical consideration. The test contained 25 items. It was administered with duration which was quite rigid, giving 60 minutes for the students to finish the test.

In the developing the test, the researcher took some steps: writing the blue-print of the test, writing the test covering the item and test validity, expert's validation, revising the test based on the comments from the expert, trying out the test, analyzing the result of the try out, and revising the test based on the analysis. To make it clear, the framework for the test development used in this research is presented in Figure 1 below. 


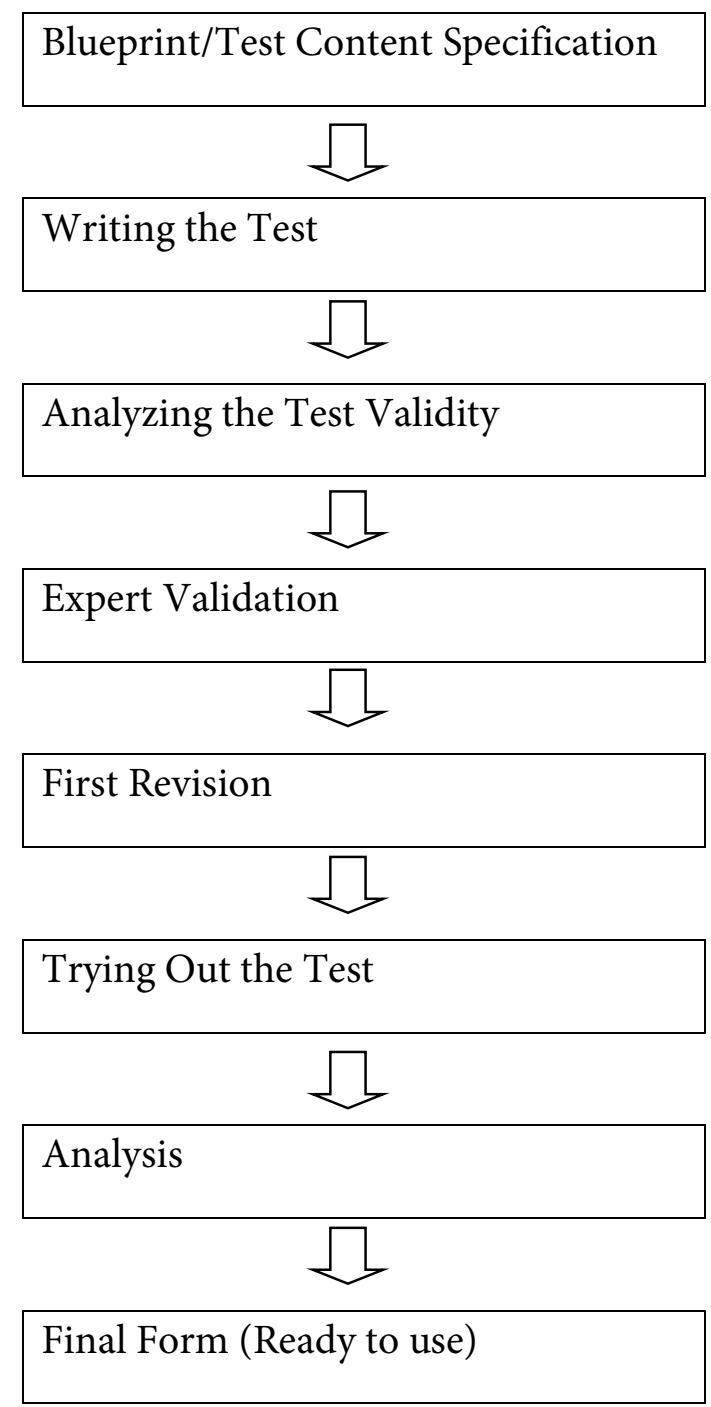

Figure 1:

The Test Development Plan

After the blueprint of the test was made, the next step in developing the test was writing the test items. The reading test was in the form of an objective test consisting of 60 items of multiple choice questions. Writing the test covered writing the direction and the items of test. The instructions were made as clear and brief as possible to ensure that the students did not get confused in reading the test instruction. 


\subsection{Data Collection}

In accordance with the research design of this study, the processes of data collection generally carried out in this study were categorized into 3 steps or stages. Those are pretest, treatment, and posttest.

Pretest is conducted in the first meeting. This is intended to see the students' preliminary competence in reading. Besides, the aim of the pretest was to know that the experiment and control group have no significant differences in their level of ability in reading comprehension.

Based on the result of the pretest, the mean score for the experimental group was 73.67 while the mean score for the control group was 70.63. To more understandable, the average score of the experimental and control groups in the pretest score can be seen in the histogram shown in Figure 2.

\section{MEAN SCORE OF PRE-TEST SCORE}

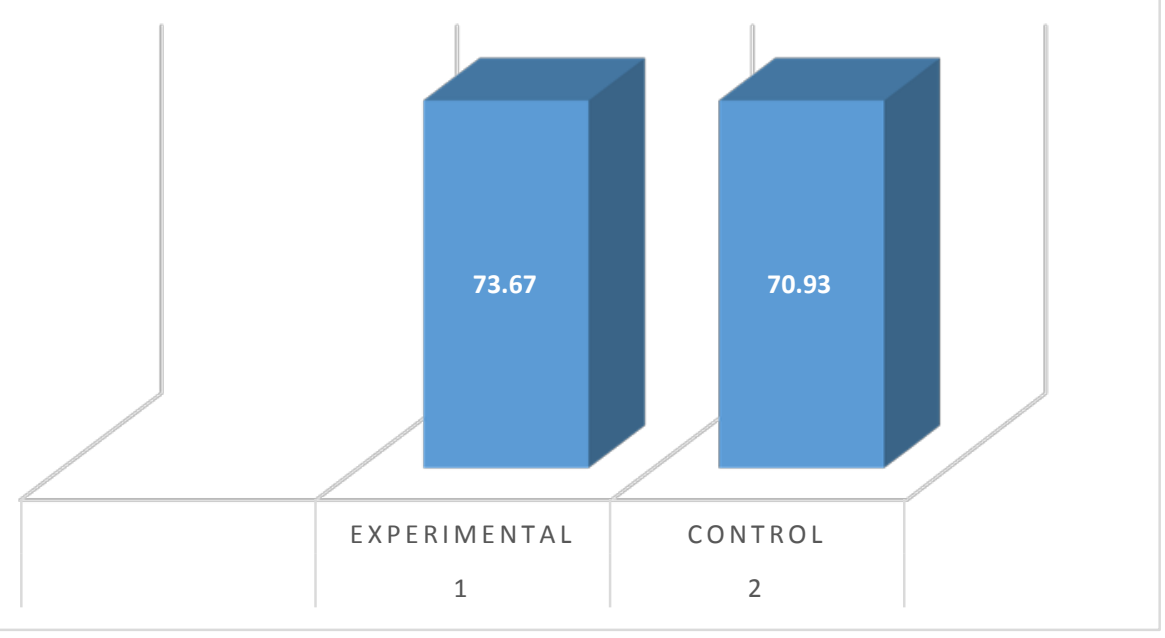

Figure 2.

The Mean Difference between the Experimental and the Control Group in the Pretest 


\subsection{Data Analysis}

The treatment process was carried out in eight meetings which were divided into three stages: modeling, guiding, and practicing stage. The treatment process was carried out for eight meetings based on the consideration that the two stay two stray strategy was relatively new for the students so that they have to be trained several times before it measured the effectiveness of the two stay two strategy.

The final steps of the data collection were administering the posttest when the subjects of the two groups have undergone the teaching learning process. After conducting the posttest, the students were given an attitude questionnaire.

Data analysis aimed at testing the research hypothesis that was, the students of eighth graders who taught by two stay two strategy achieve better in reading comprehension achievement than those taught by conventional strategy at MA Darul Ulum Gondanglegi Malang. Further, the data in this study were first of all organized and summarized using descriptive statistics.

The data of the reading comprehension test obtained in this study was organized by arranging the measure into a frequency distribution and presenting them in the graphical forms. In this study, the researcher organized the data into frequency distribution which facilitated the computation of the statistics. After that, the data was presented in graphic form. It was more helpful and convenient to present research data in a graphic form. In this research was organized the data into frequency distribution which facilitated the computation of the statistics. After that, the data was presented in graphic form. It was more helpful and convenient to present research data in a graphic form. It was often helpful and convenient present research data in a graphic form and, in this study, the data presentation frequency polygons was presented.

Furthermore, after the data was organized, it was summarized which aimed of finding a single index that can represent a whole set of measures. The mean, median, and mode are measure on central tendency or averages. The mean is the sum of all scores 
in a distribution divided by the number of cases. The median is the middle scores in the distribution of scores, and the mode is the most frequently occurring score in the distribution.

In addition, the variability of the data was measured in this study. Variability is the amount of dispersion of scores about a central value. So, one stop in the calculation of the standard deviation is to subtract the mean from each score. The resulting deviation score are then squared and entered into formula to yield the standard deviation.

In addition, there were three satisfactory assumptions that need fulfillments: normality, linearity, and homocedasticity. Normality test of variables can be conducted through the SPSS version 16 by using descriptive program in which measures of skewness are produced for distribution of variables. The value reported for skewness equals zero if the distribution was normal. To determine whether or not the value of skewness for a variable differs significantly from zero, a comparison against the standard error for skewness is needed. The method was based on the nonparametric method of hypothesis of which was formulated as follows:

$=$ The data followed the normal dispersion (parametric)

$=$ The data did not follow the normal dispersion (nonparametric) 
Table 3.

The Computation for Normality Assumption

One-Sample Kolmogorov-Smirnov Test

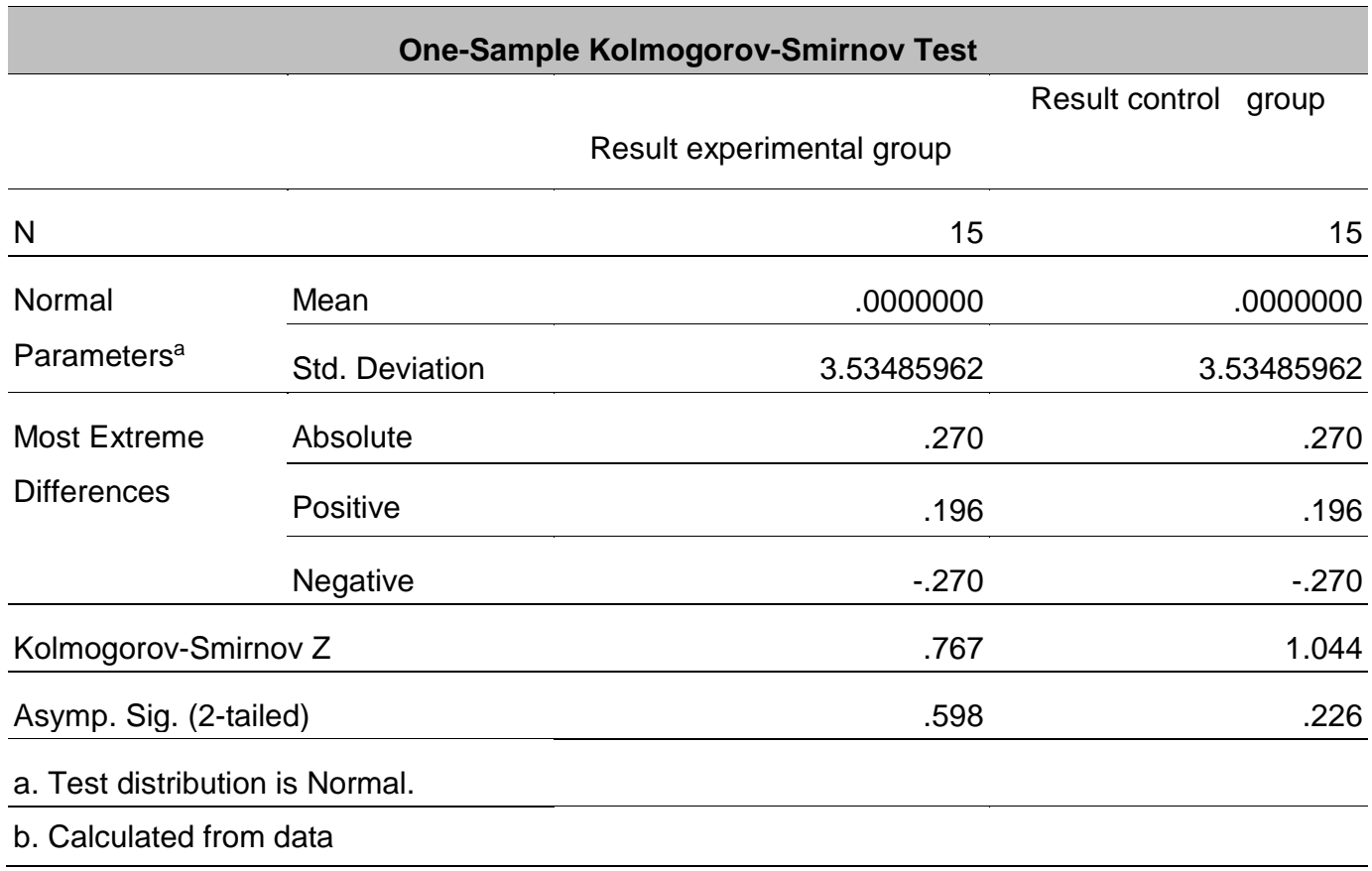

Based on the data, the $\mathrm{Z}$ value for the result of experimental group was .767 of which the significant value was .598. In additional, the $\mathrm{Z}$ value for the result of the control group was 1.044 of which the significant value was .226. Based on the computation, the significant value was bigger than $a(.05)$. As a result, the $\mathrm{H}_{0}$ was accepted. In other words, the data followed normal dispersion and the normality assumption was fulfilled.

In addition, the assumption of homoscedasticity is that the variability in score on one variable is roughly the same at all values of other variable. When heteroscedasticity is present the relationship between the variables maybe lawful, but it is not captured totally by the correlation coefficient. An analysis based on the correlation 
will underestimate the extent of relationship between variables. To estimate the heterocedasticity of the data, the Levene's test was utilized which the hypothesis was as follows:

$\mathrm{H}_{0}=$ the variances of the data are equal or homogenous

$\mathrm{H}_{1}=$ the variances of the data are different or heterogeneous

Table 4.

Levene's Test of Equality of Error Variances

\begin{tabular}{ccccc}
\hline & $F$ & df1 & df2 & Sig. \\
\hline Pretest & 1.947 & 5 & 24 & .124 \\
\hline Posttest Score & 1.847 & 14 & 15 & .125 \\
\hline
\end{tabular}

Based on the table, the observed significance level for the Levene's test is .124. Since the significance level that the researcher used is .05 (95\% confidence), thus the observed significance level for the Levene's test is higher than the level of confidence used in this study. Therefore, the experimental and control groups variance are equal.

In analyzing whether or not there was a linear relationship between the variables in this study, the scatter plot was utilized to show the accurate relationship. The hypothesis used was $\mathrm{H}_{0}=$ there was no linear relationship while the $\mathrm{H}_{1}=$ there was linear relationship. 


\section{Normal Q-Q Plot of posttest Experimental}

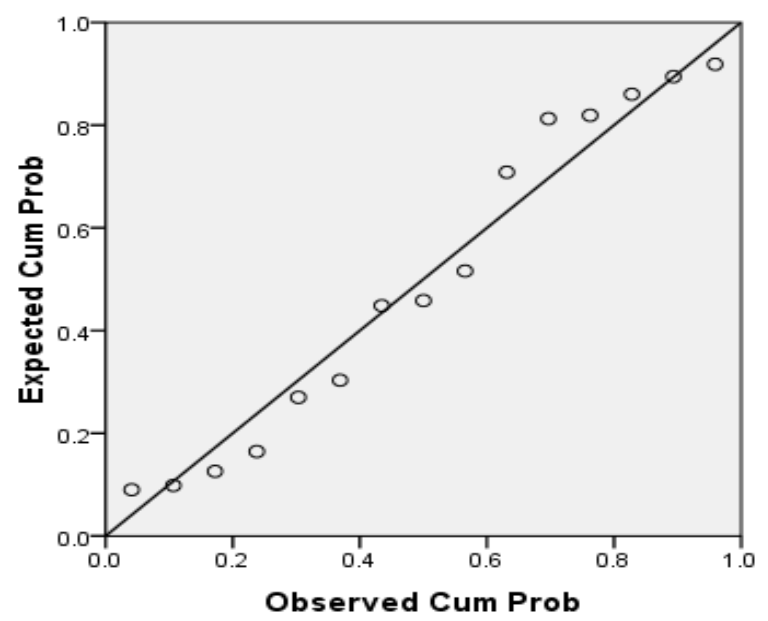

Figure 3.

The linearity Between the Data of Experimental Group

Where:

$\mathrm{o}=$ observed

- = linear

Based on the Figure 3 above, most of the points were in a place around the line thus, $\mathrm{H}_{1}$ was accepted. It meant that there was a linear relationship between the pretest and the posttest score of the experimental group. 
Normal Q-Q Plot of the Posttest Control

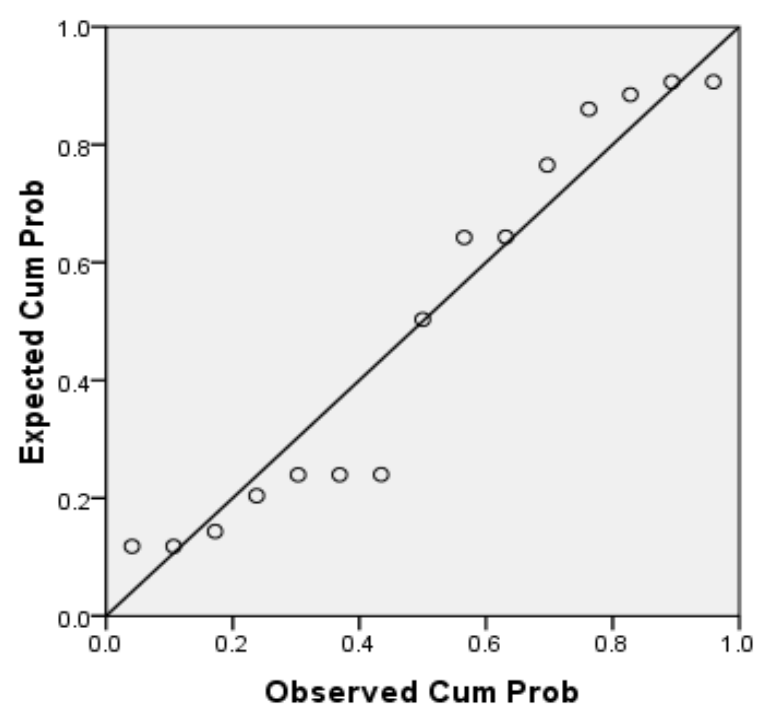

Figure 4 .

The Linearity Between the Data of Control Group

Where:

$\mathrm{o}=$ observed

- = linear

Based on the Figure 4 above, most of the points were in a place around the line thus, $\mathrm{H}_{1}$ was accepted. It meant that there was a linear relationship between the pretest and the posttest score of the control group.

Furthermore, the hypothesis of the study should be stated statistically as the following:

Null Hypothesis (H01): There is no significant difference in the reading comprehen-sion between students taught using the two stay two stray and the jigsaw strategy.

$\mathrm{H} 01: \mu \mathrm{A} 1=\mu \mathrm{B}$ 
Alternative hypothesis (Ha1): There is a significant difference in reading compre-hension between students taught using two stay two stray and those who taught using the jigsaw teaching strategy.

Hi1 $: \mu \mathrm{A} 1 \neq \mu \mathrm{B}$

After stating the null hypotheses, the researcher carried out a test of statistical significance to determine whether the null hypothesis can be rejected (to determine whether there actually was a difference between both groups). Thus, in order to accept or reject the hypothesis, the criteria direct of acceptance or rejection of the null hypothesis are to be stated. The following criteria direct us to consider whether the hypothesis is accepted or reject. $\mathrm{H}_{01}$ is accepted if the computed value of $\mathrm{F}$ is equal and less that the $\mathrm{F}$ distribution for degrees of freedom = 1, $\mathrm{df}$ for within-group $=15$ and $0,05 \%$ level of signifivant that is. .125 . Based on the basis of statistical tests, if the observed value of $\mathrm{F}$ is greater than the TS-TS. According to Ary et al $(2010 ; 184)$ the layout for an experiment investigating the combined effect of two or more independent variable is called factorial design. And the result are analyzed by means of this study was computated by means of SPSS version 16.0.

\subsection{Analysis the Data Using One Way ANOVA}

To examine the hypothesis of the study, data analysis was statistically conducted. The data which were in the form of scores representing the students' reading comprehension of the experimental and control groups were analyzed. It was used to determine whether the mean scores obtained by the students in the two groups after treatment were significantly different. In analyzing the data of posttest, the researcher used analysis of variance (ANOVA) from SPSS version 16 computation. 


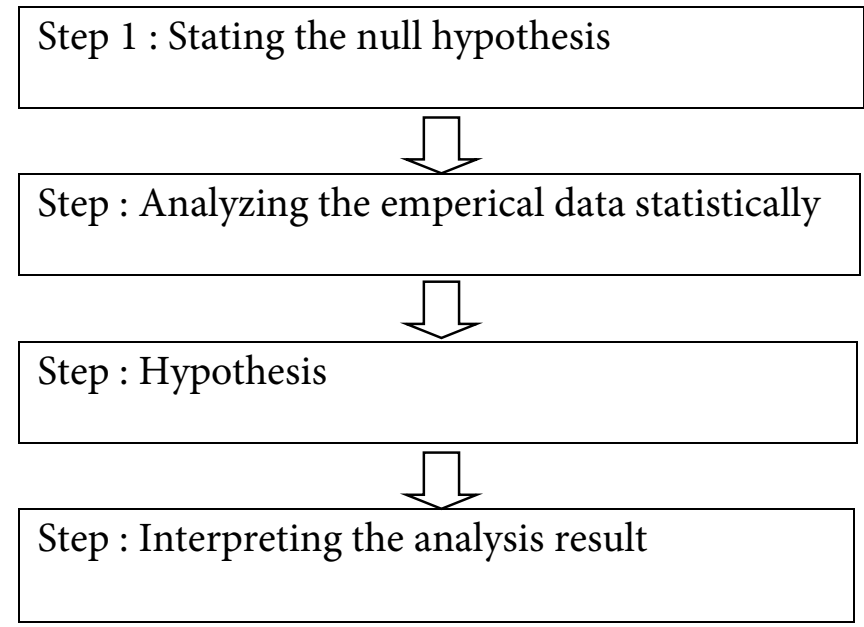

Figure 5.

The Step in Hypothesis Testing

\section{RESULTS}

The main data in this study is the students' reading comprehension score of the experimental and control group obtained from the posttest. After giving a different treatment to both group, a posttest was administered to get the data of their reading comprehension. The treatment given to the experimental group was teaching reading comprehension by using the story mapping strategy while the control group was teaching reading comprehension by using the conventional strategy.

The summary of the result of the posttest of the experimental and control group is presented in Table 5. The data obtained in the posttest was computed by using One Way ANOVA by means of SPSS version 16 
Table 5.

The Result of the Posttest of the Experimental and the Control Groups Descriptive post-test

\begin{tabular}{|c|c|c|c|c|c|c|c|c|}
\hline \multicolumn{9}{|c|}{ Descriptives } \\
\hline & \multirow{2}{*}{$\mathrm{N}$} & \multirow{2}{*}{ Mean } & \multirow{2}{*}{$\begin{array}{c}\text { Std. } \\
\text { Deviation }\end{array}$} & \multirow{2}{*}{ Std. Error } & \multicolumn{2}{|c|}{$\begin{array}{l}95 \% \text { Confidence } \\
\text { Interval for Mean }\end{array}$} & \multirow{2}{*}{ Min } & \multirow{2}{*}{ Max } \\
\hline & & & & & $\begin{array}{l}\text { Lower } \\
\text { Bound }\end{array}$ & $\begin{array}{l}\text { Upper } \\
\text { Bound }\end{array}$ & & \\
\hline $\begin{array}{l}\text { Score of Posttest of } \\
\text { experimental group }\end{array}$ & 15 & 82.67 & 5.381 & 1.389 & 79.69 & 85.65 & 76 & 100 \\
\hline $\begin{array}{l}\text { Score of posttest of control } \\
\text { group }\end{array}$ & 15 & 76.26 & 6.863 & 1.772 & 69.87 & 77.47 & 61 & 83 \\
\hline Total & 30 & 78.17 & 7.593 & 1.386 & 75.33 & 81.00 & 61 & 100 \\
\hline
\end{tabular}

Based on the result of the computation, that in the experimental group using story mapping strategy, mean score is 82.67 , while in the control group is 76.26 .

Anova post-test

\begin{tabular}{cccccc}
\hline \multicolumn{5}{c}{ ANOVA } \\
\hline & Sum of Squares & Df & Mean Square & $F$ & Sig. \\
\hline Between Groups & 607.500 & 1 & 607.500 & 15.977 & .000 \\
\hline Within Groups & 1064.667 & 28 & 38.024 & & \\
\hline Total & 1672.167 & 29 & & & \\
\hline
\end{tabular}

Table 6.

Analysis using One Way Anova

Based on the statistical computation, that a significance $.000<.05$ with the level of confidence $95 \%(\alpha=.05)$. It means that is valid. While the effect of story mapping to posttest score is .000 . It $<.05$ with the level of confidence $95 \%(\alpha=.05)$. It means that there is a significance of story mapping strategy in the students' reading comprehension. 


\section{DISCUSSIONS}

Based on the data analysis, the results of the present study are discussed. Two parts of the research finding respectively cover the discussion. The first part of the discussion is concerned with the students' reading comprehension score in the pretest and posttest both for the experimental and control group. The second part of the discussion deals with the interpretation of the result of the data analysis and in relation with the existing theories.

\subsection{The Effectiveness of Teaching Strategy with Two stay two stray Strategy on Reading Comprehension of Students' Achievement.}

The result of the final data analysis presented in Chapter IV, which has been derived from the analysis of ANOVA by which is rejected, revealed that there is any diference in the students' reading comprehension achievement between students taught by using TS-TS technique and those with the Jigsaw technique.

Before the treatment was carried out, the mean score of the experimental group on the reading score was 73.67 while the mean score of the control group on the reading score was 70.93. The mean difference between the experimental and control group was. 2.73. In the posttest, the mean score of the experimental group was 82.67 while the control group was 76.26. The mean difference between the experimental and control group was 6.40 .

The significant improvement on the posttest score of the experimental group was affected by several reasons. First, the implementation of the TS-TS technique helped students to organize the information they got from the reading material in affective way. By training students to find keywords of each paragraph and write down the information of the keywords provided the opportunities for students to recall the detail infromation from the reading materials. Then, the summarizing activities also force them to analyze and evaluate the information. By doing all of those activities, the students were trained to think critically in every meeting. Second, the implementation of the TS-TS prevented the students' boredom as the never felt before. The 
motivation of the students in the experimental group was increased or at least remained. This is based on the result of students' attitude questionnaire. Therefore, the TS-TS technique is an effective ways in improving students' reading comprehension achievement.

Although, the teaching strategy taught to the control group, that was Jigsaw technique, did not successfully improve the control group's score, the teaching taught to the experimental group that was the TS-TS technique, had a higher effect in improving the students' reading comprehension achievement of the experimental group. These finding, thus, in line with what Aris Julian Arianto (2015) and Melia Yulia (2012) found in their research that the TS-TS successfully improve the students' reading comprehension achievement.

Moreover, there are nine indicators of the test items that the students should achieve in accomplishing the reading comprehension test. As stated in the blueprint of the reading comprehension test, the nine indicators of the test items consists identify topics of paragraph, identify main idea of text, identify main idea of paragraph, identify specific information in the text, identify detail information in the text, identify inference, identify reference, identify vocabulary skill (synonym). Those nine indicators of the test items based on reading skills of reading. Reading skills of reading skills are; identify main ideas, topic, specific information, detail information, inference, reference, and vocabulary skill.10 In this study, then the achievement of the students in comprehending of the narrative texts was measured based on the nine indicators stated in the blueprint of the reading comprehension test. Accordingly, based on the result of this study, there is significant difference in identify topics of paragraph, identify main idea of text, identify main idea of paragraph, identify specific information in the text, identify detail information in the text, identify inference, identify reference, identify vocabulary skill (synonym) based on the information provided between students taught by applying the two stay two stray strategy and those taught by using the jigsaw strategy. 


\subsection{The Relationship of the Research Finding with the Earlier Theories and Previous Studies}

In relationshippto the research finding, it is found that there is significant difference between the mean scoreeof the students in the experimental and control group. Therefore, the gained score in the experimental group led to the rejection of the first null hypothesis stateddin Chapter III, on the other hand, the research hypothesis works. In other words, teaching reading by applying the TS-TS technique was significantly moreeeffective than applying the Jigsaw technique, especially in improving the students' readinggcomprehension achievement.

Based on the researchhfindings, although the posttest score of the experimental group is significantly better the control group, the posttest scoressof the experimental grouppimproved, but the posttest of the control group dropped. This means that the TS-TS technique is effective in improving the students' reading comprehension achievement. Maulani ${ }^{6}$ said that, "By using Cooperative Strategy, Two Stay Two Stray, they were more encourage, could understand the material easily, and concentrated more and spoke more confidently". Thus, looking at the improvement of the experimental group, this research findings support the earlier theories about the TSS technique.

Furthermore, as stated previously, there is a significant difference between the mean scores of the students in the experimental and control group. Since the experimental group is taught by the TS-TS technique and the control group is taught by the Jigsaw technique, the TS-TS technique is more effective than the conventional strategy in improving the students' reading comprehension. Thus, this research finding is line with the research finding carried out by Aris Julian Arianto. The result of the study carried out by Aris Julian Arianto, revealed that the TS-TS technique was significantly in improving the students' reading comprehension achievement.

\footnotetext{
${ }^{6}$ Maulani, A.F "Improving Students's speaking motivation through the use of coorepartive learning strategy in grade 2 of Madrasa Aliyah Negeri, (Yogyakarta, 2012)
} 
Besides, the finding of this research supports the previous studies about the TS-TS. The result of data analysis is significantly better than those taught by the Jigsaw technique. Thus, the students taught by the TS-TS technique are better in capturing and organizing the main gist and aiding comprehension of written passages. This research findings is in line with the result of the carried out by several researchers previously. The writer, Aris Julian Arianto (2015), conducted two stray two stay strategy in Reading comprehension through Experimental design. After conducted the treatment, the strategy was successful in improving the students reading achievement. The avarage score improved from 70 in pre-test and developed to 97 in post test. It also showed that the students' participate was $90.12 \%$.

The TS-TS technique is effective in improving the students' reading comprehension achievement may be caused of some reasons. First, by doing the TS-TS technique while reading the texts, the students can find the main idea, inferrence and can improve the students' vocabulary. The key concept of finding the main idea is to determine the most important point in certain selection of the text. Meanwhile, the key point of inference are drawing conclusion, extracting the implied meaningn from the selection and making connection with the students's background knowledge. The role of TS-TS can cover the needs of those reading skills. The TS-TS provided the students with framwork in which they can put the ideas in. The TS-TS leads the students to the concepts.

Second, the students taught by the TS-TS technique have higher motivation in reading the texts. Based on the result of the attitude questionnaire given after treatment, the result showed that most of the students enjoy reading the text. The TS-TS technique gives students a new learning experience that they never got before. Further, the students also recommend that the TS-TS technique should be applied in other subjects besides the reading class.

Third, the TS-TS technique can avoid the students' boredom while reading the texts. In the reading class applying the TS-TS technique, the students are engaged in an ongoing activity while reading the text. In every paragraph of the reading text, the 
students are asked to complete the TS-TS technique $\left(1^{\text {st }}-4^{\text {th }}\right.$ treatment $)$ or to make TS-TS freely $\left(5^{\text {th }}-8^{\text {th }}\right.$ treatment) based on the information from the texts. This activity avoids the students' boredom since in every minute of the reading class they have to practice their critical thinking the keywords of each piece of information in reading text. The TS-TS makes it more clear to students what they are expected to do and allow students to focus on what is important. Finally, the RS-TS provides mental framework for helping students to organze knowledge and build the framework peace, linking it to other learned framework. It is clear that the use of the TSTS technique helps students to focus on what is important. Further, the mental framework to organize knowledge needs the contribution of the cognitive processes.

\section{CONCLUSION AND SUGGESTION}

\subsection{Conclusion}

Based on the research problem and the result of the data analysis, it can be concluded that there is any difference in students' reading comprehension achievement taught by using the TS-TS technique and the Jigsaw technique. Thus, the teaching of the TS-TS technique in reading comprehension has impact on the students' reading comprehension achievement than the teaching of reading skill using the Jigsaw technique.

This study shows the effectiveness of the TS-TS technique on students' reading comprehension which is consistent with the result of several previous studies. As there are not many studies on the effectiveness of the TS-TS technique on students' reading comprehension achievement, some limitations of this study are presented. First, the guidance in summary activity while doing the TS-TS technique needs to be improved. During the treatment, the main attention of the researcher is how to rain the students in finding the keyword of reading text since most of students face difficulties in finding the keywords of the reading text in the beginning of the treatment. Future studies should emphasize on finding the words activity, the main idea, inference and improving the student's vocabulary since all of them are part of the TS-TS 
technique. Second, the diffusion possibly occured during the treatment since the experimental classroom is next to the control group classroom. The diffusion possibly occured when participants in the experimental group (XA) communicate information about the treatment to subject in control group $(\mathrm{XB})$ in such way influenced the letters' behavior to the dependent variable. For further investigations, diffusion can be controlled by emphasizing the fact that an experiement is going on involving differences between the groups.

\subsection{Suggestion}

Based on theeresult of the research, the result of this research have both theoretical and practical contributions to considerralternative and effective strategies to develop teaching and learning English.

Theoretically, the finding of this research reveal that this study is valuable in testing the effectivenesssof the TS-TS technique on students' reading comprehension. Besides, the finding of this research gives some more additional theory regarding with the use of TS-TS in the area of reading comprehension as previously defined by Aris Julian Arianto (2015).

On the other hand, the result of this study gives practical contribution to the school committe, English teachers and other researchers. For the school committe, the finding of this research can be as one of the considerations for them to estabilish policies on the use of the TS-TS since there is empirical evidence that the use of the TS-TS technique is effective in improving the students' reading comprehension achievement. Besides the school committe can invite an invite an expert in the TSTS technique to train the English teachers in applying the TS-TS technique.

For the English teachers or lectures, the result of this research can be used as informationssdealing with teaching technique in reading comprehension. In addition, it is expected that they will use the TS-TS technique in teaching reading comprehension since some of the investigations of applying the TS-TS technique in teaching reading comprehension yielded positive result and it has been empirically 
tested in this research. The English teachers or lectures can use the TS-TS technique in their reading class since the TS-TS technique gives some benefits to the students. When the English teachers and lectures have a reading class, then they can train their students on how to make the TS-TS effectively/ the English teachers or lectures should explain well on how to find keywords, its description and the steps in the TSTS technique and then expose student with many kinds of narrative reading material so that the students will have an effective learning experience by using the TS-TS technique a lot.

For other researchers, especially for those who mean to conduct further research in the relation with this research's findings, hopefully that further experimental studies dealing with the Jigsaw technique can be conducted in different subjects of study. Research on applying in the TS-TS technique in higher level of education is highly recommended. Since for those of students in higher level education have much more materials to read and much wider knowledge than of students of Junior high. Thus, is gives more challenges in invistigating the effectiveness of the TS-TS technique for college students.

Since the students' reading comprehension achievement in this study was assessed by a set of reading comprehension test, future research may be assesses by utulizing the non-test format such as making summary as the achievement since the summary activity is also part of the TS-TS technnique in reading comprehension. Therefore, the investigation of the effectiveness RS-TS technique both in different area of language skill and different level of students still need to be carried out.[] 


\section{REFERENCES}

Ary, D., Jacob, L.C., Razavieh, A., \& Sorensen, C. (2006). Introduction to Research in Education. Belmont: Vicki Knight.

Depdiknas. (2006). Permendiknas 2006 tentang SI \& SKL. Jakarta: Departemen Pendidikan Nasional

Donald ary et al. (2010). Introduction to Research in Education, Canada: WadswortCengage Learning

Endang fauziati, (2002). Teaching of English as a Foreign Language Surakarta: Muhammadiyah Press

Granados, Guadalupe Vázquez and Gustavo Hernández López, (2008). Ten suggestions for solving reading problems in English, Universidad de Quintana Roo - Departamento de LenguayEducación

http ://www.nclcr.org/ essentials/reading/ reindex.htm accessed on October, 24, 2014

Maulani, A.F (2012). "Improving Students's speaking motivation through the use of cooperative learning strategy in grade 2 of Madrasa Aliyah Negeri, Yogyakarta: UIN Sunan Kalijaga 